Revista de
Economild
Contemporâned

Articles

\title{
PUBLIC AND PRIVATE ANTITRUST ENFORCEMENT FOR CARTELS: SHOULD THERE BE A COMMON APPROACH TO SANCTIONING BASED ON THE OVERCHARGE RATE?
}

\author{
Yannis Katsoulacos ${ }^{a}$ \\ Evgenia Motchenkova ${ }^{b}$ \\ David Ulph ${ }^{c}$
}

\begin{abstract}
${ }^{a}$ Department of Economic Science, Athens University of Economics and Business. Athens, Greece. ORCID: https://orcid.org/0000-0002-0232-1225.

${ }^{b}$ Department of Economics, Vrije Universiteit Amsterdam, TILEC and Tinbergen Institute. Amsterdam, The Netherlands. ORCID: https://orcid.org/0000-0003-2535-4350.

'School of Economics and Finance, University of St Andrews. St Andrews, Scotland. ORCID: https://orcid.org/0000-0003-3171-1270.
\end{abstract}

Manuscript received on 2018/04/26 and accepted for publication on 2018/12/04.

\begin{abstract}
We review recent theoretical literature pointing to the ineffectiveness, in terms of welfare impact, of currently applied sanctioning regimes for cartels by Competition Authorities (CAs). We then provide a comparison of the regimes taking also into account criteria related to ease of implementation and transparency. We argue the case for switching to a penalty regime, in which the penalty base continues to be the currently dominant penalty base of cartel revenue but in which, in contrast to current practice, the penalty rate is based on the rate commonly estimated in order to calculate damages in private damage claims, that is, the overcharge rate.
\end{abstract}

KEYWORDS: antitrust penalties; antitrust enforcement; antitrust law; cartels.

JEL CODES: L4; K21; D43.

Corresponding Author: Yannis Katsoulacos

E-mail address: yanniskatsoulacos@gmail.com 


\section{APLICAÇÃO DA LEGISLAÇÃO ANTIMONOPÓLIO PÚBLICA E PRIVADA AOS CARTÉIS: DEVE HAVER UMA ABORDAGEM COMUM PARA SANCIONAR COM BASE NA TAXA DE SOBRETAXAS?}

RESUMO: Analisamos a literatura teórica recente que aponta para a ineficácia, em termos de impacto no bem-estar, dos regimes de sanção atualmente aplicados aos cartéis pelas Autoridades de Concorrência (ACs). Em seguida, fornecemos uma comparação dos regimes levando em conta critérios relacionados à facilidade de implementação e transparência. Argumentamos a favor da mudança para um regime de penalidade, no qual a base de penalidade continua a ser a atual penalidade dominante da receita do cartel, mas em que, diferentemente da prática atual, a penalidade é baseada na taxa comumente estimada para calcular os danos em sinistros de danos privados, isto é, a taxa de sobretaxa.

PALAVRAS-CHAVE: penalidades antitruste; aplicação de leis antitruste; lei antitruste; cartéis. 


\section{INTRODUCTION ${ }^{1}$}

The imposition of sanctions have been regarded as the most important ex ante public enforcement instrument that Competition Authorities (hereafter CAs) can use in antitrust and, more specifically, cartel violations. ${ }^{2}$ It is complemented by private enforcement in the form of private damage actions. In principle, by imposing sanctions for infringements, public enforcement's main objective is to deter violations (deterrence effect) and to induce non-deterred colluding firms to charge lower prices (price effect), while private damages focus on compensating those who have suffered harm. Clearly, each method can contribute to the objectives of the other. Public enforcement can facilitate and stimulate private damage actions and private damage actions can contribute to deterrence and provide incentives to customers to discover and report price-fixing. This paper reviews recent literature pointing to the ineffectiveness, in terms of their welfare impact, ${ }^{3}$ of currently employed monetary penalty schemes by CAs, ${ }^{4}$ and argues the case for CAs switching to a more effective penalty regime, in which the penalty base continues to be the currently dominant penalty base of cartel revenue, but, in which, in contrast to current practice, the penalty rate is based on the rate commonly estimated in order to calculate damages in private damage actions, that is, the overcharge rate.

1 We are grateful to Joe Harrington, Frederic Jenny, Tom Ross, Maarten Pieter Schinkel, Simon Roberts as well as the participants of the 12th Annual CRESSE Conference (July 2017) and the GDEC-CRESSE International Workshop on Advances in Competition Policy (Rio de Janeiro, November 2017) for helpful comments on our papersrelated to the subject of antitrust sanctioning. Also, we are grateful to the Tinbergen Institute, Vrije Universiteit Amsterdam, Short-term Visitor Program for the financial support.

2 The theory of sanctioning on dominant firm abuses is still undeveloped. Other important ex ante instruments of competition law enforcement in the area of cartels are the prohibition of facilitating practices (which can increase the viability of cartels), and the use of merger policy (to reduce the likelihood of cartels emerging after mergers). Ex post measures include the improvement of detection and prosecution rates, the adoption of measures to prevent recidivism and the application of leniency policies.

3 The continuing high prevalence of cartels across markets, confirmed by extensive empiricalevidencealso testifies to this. See e.g. Levenstein and Suslow (2011, 2012, 2014), Schinkel (2007), Veljanovski (2007), Connor and Lande (2008), Allain et al. (2011), Boyer and Kotchoni (2015) or Spagnolo and Marvão (2016) for an overview. This, of course, is not the only potential inadequacy in public enforcement and recent literature has also pointed to the ineffectiveness of monetary penalties, as currently applied, in inducing desirable price effects - see Bageri et al. (2013), Katsoulacos and Ulph (2013) and Katsoulacos et al. (2015).

4 There is a variety of different types of sanctions with different emphasis placed on each type over time and in different countries. Here we concentrate on monetary penalties on corporations. The other main types of sanctions in public enforcement are: financial penalties on managers involved in price-fixing, criminal sanctions/imprisonment of individuals involved in price-fixing, and debarment of individuals involved in price-fixing, from further employment in a position from which they could again violate antitrust laws. See for a review Katsoulacos et al. (2017). 
The extensive and still growing literature by economists on monetary penalty regimes ${ }^{5}$ examines and compares alternative types of such regimes, concentrating on a comparison of their welfare properties. It is nevertheless recognised that, while this comparison is very important, in order for it to have practical policy significance, a number of other policy-relevant dimensions of the regimes have to be assessed and compared. Specifically, a more complete comparison must take into account the following three dimensions / assessment criteria:

i) Implementability. This involves considerations relating to the administrative cost of the penalty regime, ${ }^{6}$ the extent to which it minimises delays in the CA enforcement process ${ }^{7}$ and the extent to which it minimises the costs of appeals in the judicial review process. ${ }^{8}$ The latter will be higher the more the appeals that are induced, against the CA's penalty decisions, by a penalty regime. The number of appeals will be greater the more likely it is that the penalty regime can lead to estimation errors and/or when penalty decisions can be easily challenged as being discriminatory.

ii) Transparency/Certainty. Penalty regimes differ in terms of how easily and accurately firms can predict the fine that they will be facing if they are prosecuted and are found to violate the law. When firms cannot predict the estimates of penalties that the CA will make, were it to investigate and condemn their conduct, there is a lack of transparency or uncertainty. ${ }^{9}$ We consider transparency/ certainty a desirable feature of a penalty regime taking the view of a large number of jurisdictions (including the EC, US, Canada and Brazil) that to achieve deterrence targets the agencies must rely on the threat of severe penalties coupled with a significant fear of detection. While it is known that in a few cases agencies adopt the view that some uncertainty can improve deterrence, when detection

5 See e.g. Harrington (2004, 2005), Buccirossi and Spagnolo (2007), Harrington (2010), Houba et al. (2010), Bageri et al. (2013), Katsoulacos and Ulph (2013), Dargaud et al. (2015), Katsoulacos et al.(2015, 2017), Bos et al. (2017).

6 The cost required in order to collect the necessary information and to undertake the estimation of the penalty by the CA and the firms.

7 The more the information required and the more difficult it is to obtain reliable data on this information the more lengthy will be the process of estimation and hence the greater the delay in reaching decisions.

8 That is, the cost for the CA of defending its decisions in Courts of Appeal and the cost that the firms have to incur when appealing against the CA's decisions.

9 Since penalties are generally calculated as a fraction of a 'penalty base' (such as revenues or profits) and since penalty guidelines only specify that this fraction (the 'penalty rate') will fall within a range that will depend on a large number of mitigating and aggravating circumstances, there is always some uncertainty in predicting the CA's penalty estimate in any specific case. This uncertainty increases as it becomes more difficult to obtain accurate estimates of the 'penalty base' and to calculate the appropriate 'penalty rate'. 
rates are low and the severity of penalties is constrained, this approach is recognised to have serious downsides. ${ }^{10}$

iii) Welfare properties. As noted above, it is on these that the economic literature has concentrated. While the traditional literature identified first-best optimal penalties (BECKER, 1968; LANDE, 1983), emphasizing their deterrence properties, the more recent literature has focused on comparing penalty regimes in a second-best world. It is then assumed that, as is true in practice, penalties cannot be set to deter all or even most cartels. ${ }^{11}$ It is then important, in addition to the deterrence effect, to address also the price effects of the penalty regimes on cartels that are not deterred. An extensive recent comparison of the welfare properties of most of the penalty regimes described below is contained in Katsoulacos et al. (2015).

Clearly, a penalty regime is better than another one if it is easier to implement, it generates less uncertainty and has a superior overall welfare impact. Unfortunately, regimes that are superior in terms of their welfare properties are not superior (and may be inferior) in terms of the other assessment criteria. This makes it difficult to translate results regarding the welfare properties of different regimes into proposals concerning which of these regimes should be adopted and implemented by CAs in practice.

Most CAs throughout the world have advocated simple revenue-based monetary penalties for cartels. ${ }^{12}$ Many countries also explicitly provide in their statutes for the imposition of penalties based on illegal gains (indeed 9 out of the 17 countries that participated in the ICN survey in 2008 including US and China). ${ }^{13}$ Penalties based on illegal gains can either take the place of revenue-based penalties (as in US) or they can constitute an additional penalty that is combined with the revenue-based penalty in

${ }_{10}$ Thus, it may lead to under deterrence when lower penalties are mistakenly anticipated by potential offenders or over deterrence when innocent agreements are deterred by overestimating fines. Further, and very importantly in practice, the less discretion an agency has (limiting uncertainty) the less the degree of litigation on the amount of the fine by companies fined and the lower the risk of being accused of discrimination and public criticism of subjectivity and arbitrariness. See for details on this ICN Report (2008).

11 For example, due to bankruptcy considerations, and in order not to violate the legal 'proportionality principle', most countries have legal ceilings on antitrust fines set as a \% of annual turnover. These may well make penalties insufficient and antitrust policies either completely ineffective or at best partially effective in such a way that only low prices are deterred, while high prices are still sustainable. See e.g. Buccirossi and Spagnolo (2007), Harrington (2010), Bageri et al. (2013), Katsoulacos and Ulph (2013), Houba et al. (2017) for details.

12 See for example Bageri and Katsoulacos (2014). As noted in the ICN Report (2008) 'the general view been that turnover/volume of affected commerce provides a good proxy for assessing the gravity of the behavior, both in terms of damage to consumers and illegal gain. Furthermore, such data is relatively easy to obtain' (p. 19).

13 See ICN Report (2008, p. 19). For an earlier detailed overview of the penalty structures implemented in OECD countries see the OECD (2002) report on fines. 
order to reach the overall penalty figure imposed on law violators (as in China). However, illegal gains-based penalties are rarely implemented - for example, in the US, the imposition of a penalty based on illegal gains has been implementedin only one case. ${ }^{14}$ Nevertheless, in some younger jurisdictions, in which competition law in relation to the imposition of sanctions is formulated, CAs have opted for including illegal gains-based penalties as a potential additional element that can be taken into account in calculating monetary penalties. ${ }^{15}$ However, this has not improved the implementation record of illegal gains-based penalties because of difficulties in their estimation and the uncertainty that they create. ${ }^{16}$

Most of the literature on the optimal design of antitrust monetary penalties has focused on four main regimes: damages-based regime, illegal gains-based regime, revenue-based regime and overcharge-based regime. In a recent paper, Katsoulacos et al. (2017) also examine a fifth alternative regime, the sophisticated revenue-based penalty regime. In this case, the penalty base is the revenue of the cartel, but the penalty rate depends on (and increases with) the cartel overcharge rate. Finally, we should recognise that the literature on estimating private damage claims proposes they are based on a simplified version of the damages-based penalty. Therefore, this, as well as a simplified version of an illegal gains-based regime, ${ }^{17}$ have to be included in a full comparison. Below, we turn to a comparison of these seven potential penalty regimes.

\section{BRIEF DESCRIPTION AND COMPARISONS OFTHE MAIN MONETARY PENALTY REGIMES}

Let us assume that $\left(p^{C}, Q^{C}\right)$ represent the cartel price and output, while the (potentially imperfectly competitive) 'but-for' price and output are $\left(p^{B}, Q^{B}\right)$, and $c$ is the marginal

14 As we have been informed in a private communication with Greg Werden. This is generally true as also found in the survey of the ICN (Report 2008).

15 For example, on June 17, 2016, the Chinese CA enforcing law in the area of price-related anticompetitive conduct (NDRC) published 'Draft Guidelines on the Determination of Illegal Gains and Fines in Relation to Undertakings' Monopoly Conduct, which are expected to be introduced formally this year. With these, the NDRC attempts to make illegal-gains an important part of penalty setting in China - this has been commended by Koren W Wong-Ervin et al. (2016) - though in the past, the Chinese authorities have tried to calculate illegal gains in setting penalties in only about $10 \%$ of the cases. Also, the Chilean Competition Authority (FNE) has adopted penalties based on illegal gains in 2014.

16 'Difficult to be estimated' and 'Easy to be challenged' is the standard way of explaining why penalties based on illegal gains are rarely used. Appendix 1 also provides more formal analysis to support these arguments. See, for the case of China, Deng and Katsoulacos (2017).

${ }^{17}$ If a simplified version of a damages-based regime is admitted in the comparison, it is hard to justify not to include also a simplified version of the illegal gains - based regime. 
cost ('but-for' price under perfect competition). $R^{C}=p^{C} Q^{C}$ is the cartel revenue (turnover), while $R^{B}=p^{B} Q^{B}$ is the but-for revenue. Consider first the following five potential penalties $F_{i}, i=D, G, R, O, S R .^{18}$

i) Damages-based penalties $\left(F_{D}\right)$. These were proposed in the seminal article of Becker (1968) examining first-best optimal penalties - under the assumption that the enforcing agency's objective is to maximise (total) social welfare. In this case, penalties should be the damages $(D)$, which refer to the total consumer welfare harm caused by the cartel price increase over the (counterfactual or) but-for competitive level, including the deadweight welfare loss triangle $(L)$ associated with the reduction in the volume of output by the cartel. Thus:

$$
F_{D}=D=\left(p^{C}-p^{B}\right) Q^{C}+L=\left(\frac{\theta}{1+\theta}\right) R^{C}+L
$$

In (1), $\theta=\left(p^{C}-p^{B}\right) / p^{B}$ is the proportional overcharge.

ii) Illegal gains (or profit)-based penalties $\left(F_{G}\right)$. These were early identified for their welfare properties, their adoption was proposed most forcefully by Lande (1983) for cases in which the objective is to deter conduct that does not generate any efficiencies (such as price fixing), in order to deter the reduction in consumer surplus that results from such conduct. Illegal gains are defined as cartel's profits over and above the counterfactual level of profits. ${ }^{19}$ Thus:

$$
F_{G}=\left(p^{C}-p^{B}\right) Q^{C}-m \Delta Q=\left(\frac{\theta}{1+\theta}\right) R^{C}-m \Delta Q
$$

In (2) $\Delta Q$ is the reduction in output caused by the cartel and $m$ is the absolute profit margin in the but-for situation, that is, the difference between but-for price and marginal cost. ${ }^{20}$

iii) Revenue-based penalties $\left(F_{R}\right)$. As already mentioned, these are the penalties most often adopted and implemented by CAs throughout the world. They are calculated as a multiple of actual cartel revenue, in which the fixed multiplier or

\footnotetext{
18 For a diagrammatic representation of the first two regimes see also Appendix 1.

19 In the special case in which the counterfactual price is the marginal cost (competitive price), the illegal gains are the same as the cartel profits.

${ }^{20}$ In Diagram 1 of Appendix 1 this is the area (A-B).
} 
penalty rate $\left(\rho_{R}\right)$ falls within a range that depends on a large number of mitigating and aggravating circumstances. ${ }^{21}$ Thus:

$$
F_{R}=\rho_{R} R^{C}
$$

iv) Overcharge-based penalties $\left(F_{O}\right)$. These are calculated as a multiple of the 'but-for' revenue $R^{\mathrm{B}}$. If $\rho_{O}$ is the penalty rate in this case, then

$$
F_{O}=\rho_{O} \theta R^{\mathrm{B}}
$$

v) Sophisticated revenue-based penalties $\left(F_{S R}\right)$. These use the revenue of the cartel as base, but the penalty rate depends on (and increases with) the cartel overcharge rate. Thus, if $\rho_{S R}$ is the penalty rate (written as a function of the overcharge):

$$
F_{S R}=\rho_{S R}(\theta) R^{C}
$$

We next turn to note the value of damages $(\tilde{D})$ as estimated in private damage claims. ${ }^{23}$ According to the usual approach, estimates of damages in such claims are obtained by neglecting $L$ in (1), so that:

$$
\tilde{D}_{1}=\left(p^{C}-p^{B}\right) Q^{C}=\left(\frac{\theta}{1+\theta}\right) R^{C}
$$

This is similar to (5), i.e. the penalty under a sophisticated revenue-based regime. A penalty based on this estimate of damages, i.e.

$$
\tilde{F}_{D}=\tilde{D}_{1}=\left(\frac{\theta}{1+\theta}\right) R^{C} \tilde{F}_{D}=\tilde{D}_{1}=\left(\frac{\theta}{1+\theta}\right) E\left(6^{\prime}\right)
$$

Is much easier to calculate thanin (1).

${ }^{21}$ Duration of the cartel is one of the aggravating circumstances. Some authorities use a revenue figure that is an estimate of the revenue in all years that the cartel was in place.

${ }^{22}$ In the special case in which the counterfactual / competitive price is the marginal cost (c) this is given by:

$$
F_{O}=\rho_{O} \frac{Q(c)}{Q(c(1+\theta))}\left(\frac{\theta}{1+\theta}\right) R^{c}
$$

${ }^{23}$ She Brander and Ross $(2006,2017)$. 
So $(6) /(6)$ is a simplified version of the damages-based penalty regime. We return to this below. As indicated above, we should also include a simplified version of the illegal gains-based penalty regimein the comparison. This is given by a simplified version of (2), in which $L$ is neglected:

$$
F_{G}=\left(\frac{\theta}{1+\theta}\right) R^{C}
$$

Table 1 shows the information required for calculating the above penalties. The information required is categorised as Observable $(\mathrm{O})$ or Unobservable $(\mathrm{U})$ and in accordance with the difficulty in getting the information as $\mathrm{H}$ : High, M: Medium and L: Low. This allows the comparison between different penalty regimes in terms of the criteria of implementability and transparency.

Table 1 - Information required for the calculation of alternative penalties

\begin{tabular}{|c|c|c|c|c|c|c|}
\hline $\begin{array}{l}\text { Information } \\
\text { Required }\end{array}$ & $\begin{array}{l}\text { Revenue- } \\
\text { based } \\
(3)\end{array}$ & $\begin{array}{l}\text { Sophisticated } \\
\text { revenue- } \\
\text {-based } \\
(5)\end{array}$ & $\begin{array}{c}\text { Over } \\
\text { charge- } \\
\text { based } \\
(4)\end{array}$ & $\begin{array}{l}\text { Illegal } \\
\text { gains- } \\
\text { based } \\
(2)\end{array}$ & $\begin{array}{c}\text { Damages- } \\
\text { based } \\
\text { (1) }\end{array}$ & $\begin{array}{l}\text { Simplified } \\
\text { damages- } \\
\text { and illegal } \\
\text { gains-based } \\
\left(6^{\prime}\right) \text { and (2') }\end{array}$ \\
\hline $\begin{array}{l}\text { Cartel revenue } \\
p^{C} Q^{C}=R^{C}(O ; L)\end{array}$ & $\mathrm{X}$ & $\mathrm{X}$ & & $\mathrm{X}$ & $\mathrm{X}$ & $\mathrm{X}$ \\
\hline $\begin{array}{l}\text { Cartel volume of sales, } \\
Q^{C}(O ; L)\end{array}$ & & & & $\begin{array}{c}\mathrm{x} \\
(\text { for } \Delta Q)\end{array}$ & $\begin{array}{c}\mathrm{X} \\
(\text { for } \mathrm{L})\end{array}$ & \\
\hline $\begin{array}{l}\text { Counterfactual price and, } \\
\text { hence, Overcharge } \\
\theta=\left(p^{C}-p^{B}\right)^{/} / p^{B}(U ; H)\end{array}$ & & $\mathrm{X}$ & $\mathrm{X}$ & $\mathrm{X}$ & $\mathrm{X}$ & $\mathrm{X}$ \\
\hline $\begin{array}{l}\text { Counterfactual volume of } \\
\text { sales } Q^{B}(U ; H)\end{array}$ & & & $\mathrm{X}$ & $\begin{array}{c}\mathrm{x} \\
(\text { for } \Delta Q)\end{array}$ & $\begin{array}{c}\mathrm{X} \\
(\text { for } \mathrm{L})\end{array}$ & \\
\hline $\begin{array}{l}\text { Cost Information } \\
(c)(U ; H)\end{array}$ & & & & $\begin{array}{c}\mathrm{X} \\
\text { (for } \mathrm{m})\end{array}$ & & \\
\hline $\begin{array}{l}\text { Information about Demand } \\
\text { Structure }(U ; H)\end{array}$ & & & $\mathrm{X}$ & $\mathrm{X}$ & $\mathrm{X}$ & \\
\hline
\end{tabular}

Source: Authors' elaboration.

\subsection{COMPARISONS: IMPLEMENTABILITY AND TRANSPARENCY}

According to Table 1, other than cartel revenue (which is the only information required by the simple revenue-based penalty regime) and the cartel volume of sales, which are 
observable and obtainable at low cost, all other information required for implementing the other penalty regimes is unobservable and obtainable at a medium to high cost. The following comments can be made regarding the properties of implementability and transparency from Table 1.

Damages-based penalties: since these include the deadweight welfare loss L, clearly, they are very difficult to estimate accurately because the calculation of $\mathrm{L}$ requires knowledge of the but-for price and volume of sales, hence information about the structure of demand. Thus, their estimation is likely to be subject to quite significant errors. For this reason, such penalties have very significant implementability problems and a low degree of transparency (high uncertainty) raising significantly the probability of being challenged for being false or discriminatory. For these reasons, they rarely form the basis of antitrust pubic enforcement sanctioning in practice.

Illegal gains-based penalties: these are also very difficult to estimate accurately through (2), as their estimation requires knowledge of the but-for price and volume of sales, hence about the structure of demand as well as cost information (to estimate $m$ ). Thus, their estimation is likely to be subject to quite significant errors, which implies that such penalties also have significant implementability problems and can create a low degree of transparency/significant amount of uncertainty. ${ }^{24}$

(Simple) revenue-based penalties: as is clear from Table 1, these owe their popularity to the fact that they score high in terms of easiness of implementability and also on transparency (low uncertainty). ${ }^{25}$

Overcharge-based penalties: their calculation is based on obtaining estimates of the price overcharge and, more importantly, the counterfactual volume of sales, hence, information about the structure of demand. ${ }^{26}$ This implies that this regime scores also low in implementability and transparency.

Sophisticated revenue-based penalties: their calculation requires the cartel revenue and estimates of the price overcharge. ${ }^{27}$ Thus, these penalties score 'moderate'

24 Nevertheless, because they are thought to have good deterrence properties, as already noted, they are sometimes included in the penalty regimes adopted, though they are very rarely implemented in practice. Concerning their welfare properties, it should be stressed that, in terms of price effects, they are inferior to overcharge-based and damages-bases penalties (KATSOULACOS et al., 2015, 2017).

${ }_{25}$ On the other hand, as mentioned below, these penalties are very weak in terms of their welfare properties.

${ }^{26}$ It is the product of these that forms the 'penalty base' of this regime. Note that providing estimates of the overcharge (or the but-for price), as it is done for private damage claims, is much easier than doing this and also providing an estimate of the but-for volume of sales. See also discussion on implementation below.

${ }^{27}$ Of the cartel under investigation. The CA can obtain these estimates of the price overcharge using the relatively simple methodologies employed in private damage claims, as described for example by Brander and Ross $(2006,2017)$. 
in relation to ease of implementation and transparency. We note that they have exactly the same easeof implementation and transparency as for obtaining standard estimates of damages in private damage claims. Further comments in relation to this are provided in greater detail below.

Simplified damage-based and illegal gains-based penalties: Exactly the same remarks as for sophisticated revenue-based penalties apply here.

Thus, we are led to the following:

- Remark 1: The above discussion demonstrates thatsophisticated revenuebased penalties are clearly superior judged in terms of easiness of implementation and in terms of transparency (low uncertainty), than the overcharge-based, the illegal gains-based and the damages-based penalties. They are equivalent to the simplified damages-based ant the simplified illegal gains-based penalties, while they do not perform as well, in terms of these criteria, as the simple revenuebased penalties.

- Remark 2: The sophisticated revenue-based monetary penalties when $\rho_{S R}(\theta)=\left(\frac{\theta}{1+\theta}\right)$ are the same asthe damages calculated in private damage claims, and the same as the simplified damages-based, as well as the simplified illegal gains-based, penalties.

\subsection{WELFARE COMPARISONS}

As we noted above, in a second-best world, in which legal and other constraints do not allow penalties to reach their first-best level ${ }^{28}$ and some cartels always form, it is important, when considering the welfare impact of cartel penalty regimes, to account for their effect on prices and not just on deterrence. Katsoulacos et al. (2015) show that the overcharge-based penalty regime $\left(F_{O}\right)$, given by $(4)$, is welfare superior to an illegal gains-based regime (given by (2)) and, especially, to the simple revenue-based regime that is currently used (given by (3)). Specifically, having selected penalty rates appropriately to ensure deterrence equivalence across different penalty regimes, by adopting the overcharge-based regime, a CA can get superior price effects (prices that are below the monopoly level). Whereas, with an illegal gains-based regime, the price of cartels will be at the monopoly level and, with a simple revenue-based regime, the price of cartels will be above the monopoly level. A damages-based penalty (given by

28 See, for example, Huba et al. (2017). 
(1)), on the other hand, has equivalent welfare properties to an overcharge-based regime. ${ }^{29}$ Thus, we can say that overcharge-based and damages-based regimes have 'strong' welfare properties, the illegal gains-based regime has 'moderate' welfare properties and the simple revenue-based has 'poor' welfare properties.

The fundamental reason why the currently used simple revenue-based penalty regime has welfare inferior price effects is that under this regime the expected penalty is decreasing in the cartel price.This induces cartels to charge prices above the monopoly level. The overcharge-based and sophisticated revenue-based regimes, on the other hand, are increasing in the cartel price, inducing cartels to set prices below the monopoly level.

Katsoulacos et al. (2017) extend the model of Katsoulacos et al. (2015) ${ }^{30}$ and show that a sophisticated revenue-based regime, given by (5) with, is welfare superior in terms of both deterrence and price effects to a simple revenue-based regime - ensuring cartel prices below the monopoly level. Thus, the welfare properties of are certainly 'strong', relative to the 'poor' welfare properties of $F_{R}$. Indeed, Katsoulacos et al. (2017) show that the welfare properties of are superior, for a large range of parameter values (though not all), to the welfare properties of the overcharge-based penalty. Finally, Katsoulacos et al. (2017) show that the sophisticated revenue-based regime is welfare superior to the simplified damage-based and the simplified illegal gains-based regimes (given by (6’) and (2'), respectively).

\subsection{OVERALL COMPARISONS}

The conclusion from the previous two sub-sections is that the only regime that does not have low ease of implementation and low transparency and, thus, the only regime that CAs could consider adopting, which also has superior welfare properties (especially relative to the simple revenue-based) penalty regime, is the sophisticated revenue-based penalty regime.

Table 2 summarizes this discussion, providing an overall comparison of the alternative penalty regimes across all the assessment criteria. It includes the simplified damages-based $\left(\tilde{F}_{D}\right)$ and the simplified illegal gains-based $\left(\tilde{F}_{G}\right)$ penalties given by:

29 While KMU (2015) do not explicitly examine damages-based penalties, it is straightforward to show see Appendix 2 - that under the latter cartel prices will also be under the monopoly level.

30 KMU (2017) consider a range of different markets in which cartels may form, rather than a single 'typical' market (as in KMU, 2015), and assume that, in order to satisfy the principle of non-discrimination or equality of treatment, the penalty rates should not vary across markets. 


$$
\tilde{F}_{D}=\tilde{F}_{G}=\left(\frac{\theta}{1+\theta}\right) R^{C}
$$

Which are exactly the damages as commonly calculatedin private damage claims.

Table 2 - Summary of discussion of assessment criteria

\begin{tabular}{lccc}
\hline Assessment criterion & Lase of Implementation & $\begin{array}{c}\text { Transparency/ } \\
\text { Certainty }\end{array}$ & Welfare \\
Damages-based, $F_{D}$ & Low & Low & Moderate \\
Illegal gains-based, $F_{G}$ & Low & Low & Strong \\
Overcharge-based, $F_{O}$ & High & High & Poor \\
Simple revenue-based, $F_{R}$ & Moderate & Moderate & Strong \\
Sophisticated revenue-based, $F_{S R}$ & Moderate & Moderate & Poor \\
Simplified damages - based, $\tilde{F}_{D}$ & Moderate & Moderate & Poor
\end{tabular}

Source: Authors' elaboration.

Thus, we have:

- Remark 3: Among all the alternative penalty regimes that are welfare superior to the simple revenue-based penalties currently used, only the sophisticated revenue-based regime is likely to be also overall superior because it fares best, relative to all these other welfare superior alternative regimes, in terms of ease of implementation and transparency.

Given that the sophisticated revenue-based regime is superior to the simple revenuebased regime in terms of both its price effects and its deterrence effects, it is likely that these beneficial effects out weight any drawbacks in terms of ease of implementation and transparency. Therefore, we conclude that serious consideration should be given to switching the monetary penalty regime under public enforcement to a sophisticated revenue-based regime. We consider this recommendation in more detail in the next section. 


\section{WHY CAS SHOULD SERIOUSLY CONSIDER SWITCHING TO THE SOPHISTICATED REVENUE-BASED PENALTIES?}

Given the current state of knowledge, as reviewed in the previous sections, the only argument that can be used in order to justify the continuing use of the current simple revenue-based monetary penalties in the public enforcement against cartels, despite their poor welfare properties, is that by doing so we avoid the implementability and transparency problems associated with getting estimates of the overcharge. Here, we take a careful look at these problems.

The implementability and transparency concerns raised by the need to calculate the price overcharge, as under the sophisticated revenue-based regime, are often vastly overstated. To explain why we consider this, we note that the overcharge in cartel cases has been a magnitude routinely estimated for many years in private damage claims to calculate damages, as given by expression (6') above. These have been a very important feature of the North America jurisdictions and were introduced in EU competition policy in 2014, becoming gradually popular in the EU countries too. It is now well recognized that there are many mature alternative methodologies for the estimation of the overcharge in damages claims that range from a low to a high degree of sophistication and so, as two prominent authors in this area wrote recently,

Overall, we feel that a great deal of progress in damage estimation and related topics has been made in the past two decades. In addition, data availability has significantly improved and computing power has increased greatly. Therefore, good estimates of damages from price-fixing and related anticompetitive practices can often be obtained. (BRANDER and ROSS, 2016; ROSS, 2006)

An often raised additional concern, when the issue of having to calculate the overcharge in order to take it into account in setting monetary penalties, is that CAs would be overburdened if they became responsible for this. As the argument goes, in private damages claims the estimation is undertaken by those claiming damages and the Courts just have to balance the evidence presented and choose between these and the counter estimates made by the defendants. However, a moment's thought indicates that this is certainly not a strong argument. There is nothing to stop the CAs to request from the parties (defendants and plaintiffs) to make their estimates of the price overcharge available, with detailed justification, together with all the other documents that they are asked to produce during the investigative procedure. Indeed, such a request, if mandatory, would likely have beneficial welfare effects since it would increase the costs to cartel offenders of being detected - having to try to show low overcharge rates before this is required for dealing with private damage claims, and would incentivise plaintiffs not to make false claims of law violation. Of course, there would be cases, in which there would 
be no claimants and the CA would open an investigation ex officio. But in these cases too, it is certainly possible, and this has been the standard practice in ex officio investigations, for the CA to call on those that have been harmed by the cartel and to request them to provide evidence of the extent to which they were harmed - hence, of the overcharge rate. Clearly, these third parties would have ample incentives to provide this information since this wouldalso be used in private damages claims.

\section{CONCLUDING REMARKS}

Taking into account the above arguments, it seems very strange that, if it is so widely accepted to pay damages (as estimated in practice, using (6) or (7)), under private enforcement, there is an opposition ${ }^{31}$ to doing essentially the same - i.e. base the calculation of monetary penalties on an expression like (5)- under public enforcement. One possible explanation for this opposition is that the case has not been articulated in the past, taking into account all the considerations discussed above and, in particular, the welfare distortions of the currently used penalty regime, stressed in the recent economic literature.

Another consideration that may be relevant concerns the acceptable burden of proof under private and public enforcement. To use the US example, US Courts have held that while, for claiming damages, plaintiffs must show the existence of an injury with a 'reasonable degree of certainty', the proof of the amount of a plaintiff's damages is subject to a lower burden of proof (J. Truett Payne Co. vs. Chrysler Motors, 1981). The Supreme Court has held that damages may be shown using a "just and reasonable estimate, based on relevant data, including both 'probable and inferential as well as direct and positive proof' (Zenith Radio Corp. vs Hazeltine Research Inc., 1969). Thus, Courts have recognized the inherently lower ability to estimate damages and have accepted damage estimates based on reasoned analysis and partial information. Is there a reasonable reason why, what is accepted by Courts as burden of proof for private damages claims, should not or cannot be accepted by CAs? This is a legal rather than an economic question: should the burden of proof be higher for estimating penalties to punish and deter wrongdoing than for estimating them in order to compensate those that have been harmed by the wrong-doing? This point has not been explicitly argued and justified. For as long as this remains the case, it does not seem possible to provide a convincing case for maintaining the current policy on monetary penalties in public antitrust enforcement. This constitutes the main conclusion of this paper.

31 Beyond that associated with normal and to some extent understandable institutional inertia. 


\section{REFERENCES}

ALLAIN, M-L.; BOYER, M.; PONSSARD, J-P. The determination of optimal fines in cartel cases: theory and practice. Concurrences - Competition Law Journal, n. 4, p. 32-40, 2011.

BAGERI, V.; KATSOULACOS, Y.; SPAGNOLO, G. The distortive effects of antitrust fines based on revenue. The Economic Journal, v. 123, n. 572, p. 545-557, 2013.

BAGERI, V.; KATSOULACOS, Y.A simple quantitative methodology for the setting of optimal fines by antitrust and regulatory authorities. European Competition Journal, v. 10, p. 253-278, 2014

BECKER, G. S. Crime and punishment: an economic approach. Journal of Political Economy, $\mathrm{n}$. 76 , p. 169-217, 1968.

BOS, I. et al. Does enforcement deter cartels? A tale of two tails. In: EARIE 2016 CONFERENCE, Lisbon, Portugal, 26-28 aug. 2016.

BOYER, M.; KOTCHONI, R. How much do cartel overcharge? Review of Industrial Organization, v. 47, n. 2, p. 119-153, 2015.

BRANDER J. A.; ROSS, T. W. Estimating damages form price-fixing. Canadian Class Action Review, v. 3, n. 1, p. 335-369, 2006.

BRANDER, J. A.; ROSS, T. W. Estimating damages to direct and indirect purchasers in pricefixing actions. Canadian Competition Law Review, v. 30, n. 1, p. 1-39, 2017.

BUCCIROSSI, P.; SPAGNOLO, G. "Optimal fines in the era of whistle blowers - Should price fixers still go to prison?" In: GOSHAL, V.; STENNEK, J. (Eds). The political economy of antitrust. Amsterdam: Elsevier, 2007.

CONNOR, J. M.; LANDE, R. H. “Cartel over charges and optimal cartel fines”. In: WALLER, S. (Ed.). Issues in competition law and policy. v. 3. Chicago: American Bar Association, 2008.

DARGAUD, E.; MANTOVANI, A.; REGGIANI, C. Cartel punishment and distortive effects of fines. Journal of Competition Law and Economics, v. 12, n. 2, p. 375-399, jun. 2016.

DENG, J.; KATSOULACOS, Y. Anti-trust sanctioning in China: how can the NDRC guidelines be further improved?" Competition Policy International Antitrust Chronicle, 14 aug. 2017.

HARRINGTON, J. Cartel pricing dynamics in the presence of an antitrust authority. The Rand Journal of Economics, n. 35, v. 651-673, 2004.

HARRINGTON, J. Optimal cartel pricing in the presence of an antitrust authority. International Economic Review, v. 46, n. 1, p. 145-170, 2005.

HARRINGTON, J. Comment on antitrust sanctions. Competition Policy International, v. 6, n. 2, p. 41-51, 2010.

HOUBA, H.; MOTCHENKOVA, E.; WEN, Q. Antitrust enforcement with price-dependent fines and detection probabilities. Economics Bulletin, v. 30, n. 3, p. 2017-2027, 2010.

HOUBA, H.; MOTCHENKOVA, E.; WEN, Q. Legal principles in antitrust enforcement. The Scandinavian Journal of Economics, v. 120, n. 3, p. 859-893, 2018.

ICN - INTERNATIONAL COMPETITION NETWORK. Setting Fines for Cartels in ICN Jurisdictions. Report to the $7^{\text {th }}$ Annual Conference, Kyoto, April 2008. Luxembourg: Office for Official Publications of the European Communities, 2008. 
KATSOULACOS, Y.; METSIOU, E. “The economics of antitrust sanctioning: a brief review”. In: BONAKELET.; FOX, E.; MACNUBE, L. (Eds.). Competition policy for the new era: insights from BRICS and developing countries. Oxford: Oxford University Press, 2017.

KATSOULACOS, Y.; ULPH, D. Antitrust penalties and the implications of empirical evidence on cartel overcharges. The Economic Journal, v. 123, n. 572, p. 558-581, 2013.

KATSOULACOS, Y.; MOTCHENKOVA, E.; ULPH, D. Penalizing cartels: the case for basing penalties on price overcharge. International Journal of Industrial Organization, v. 42, p. 7080, 2015.

KATSOULACOS, Y.; MOTCHENKOVA, E.; ULPH, D. Penalizing on the basis of the severity of the offence: a sophisticated revenue-based cartelpenalty. TILEC Discussion Papers, n. $2017-$ 014. Available at: <http://www.cresse.info/uploadfiles/SSRN-KMU\%20Penalties\%20 May\%202017.pdf>.

LANDES W. M. Optimal sanctions for antitrust violations. The University of Chicago Law Review, v. 50, n. 2, p. 652-678, 1983.

LEVENSTEIN, M. C.; SUSLOW, V. Y. Breaking up is hard to do: determinants of cartel duration. Journal of Law and Economics, v. 54, n. 2, p. 455-492, 2011.

LEVENSTEIN, M. C.; SUSLOW, V. Y. Cartels and collusion - empirical evidence. Ross School of Business Paper, n. 1182, nov. 2012. Available at: $<$ http://ssrn.com/abstract=2182565>.

LEVENSTEIN, M. C.; SUSLOW, V. Y. Price fixing hits home: an empirical study of price fixing conspiracies in the US. Ann Arbor: University of Michigan, jan. 2014, mimeo.

OECD - ORGANISATION FOR ECONOMIC CO-OPERATION AND DEVELOPMENT. Fighting Hard-Core Cartels: harm, effective sanctions and leniency programs. Paris: OECD, 2002.

WONG-ERVIN, K. et al. Monetary penalties in China and Japan. GMU Antonin Scalia Law School, DP 16-40; CPI cct. 2016. 


\section{Appendix 1}

Diagram 1: Diagrammatic representation

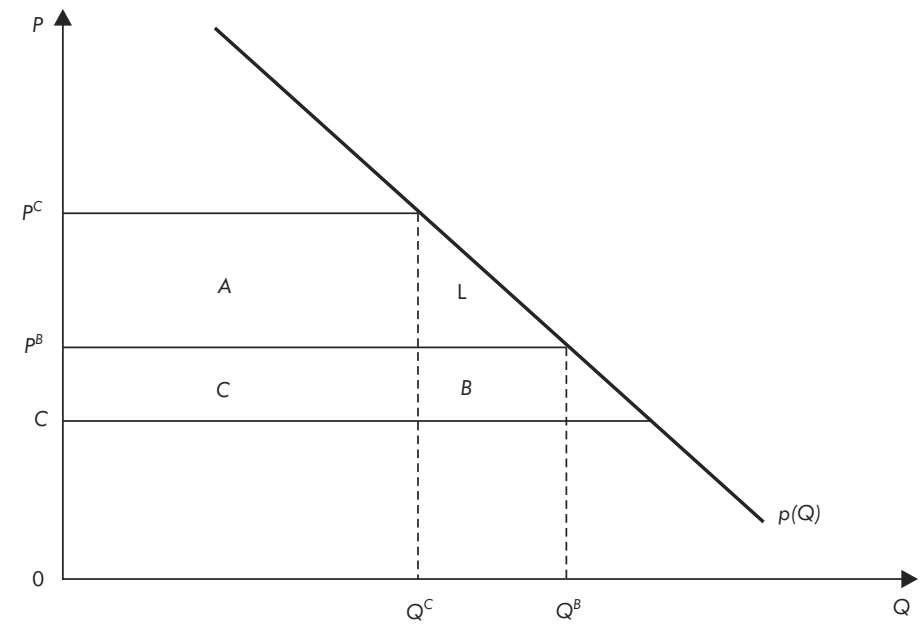

Damages-based penalty: area $A+L$

Illegal gains-based penalty: area $A-B$

\section{Appendix 2}

The price effects of a damages-based penalty

Damages is the reduction in consumer surplus compared to what would have accrued under the counter-factual "but-for" situation. They are given by:

$$
\begin{aligned}
& \left(p^{C}-p^{B}\right) Q\left(p^{C}\right)+\frac{\left(p^{C}-p^{B}\right)\left(Q^{B}-Q\left(p^{C}\right)\right)}{2}=\frac{1}{2}\left[\left(p^{C}-p^{B}\right) Q\left(p^{C}\right)+\left(p^{C}-p^{B}\right) Q^{B}\right] \\
& =\frac{1}{2}\left[\left(p^{C}-c\right) Q\left(p^{C}\right)+\left(p^{C}-p^{B}\right) Q^{B}-\left(p^{B}-c\right) Q\left(p^{C}\right)\right]
\end{aligned}
$$

Therefore, expected profits with penalties on damages are:

$$
\begin{aligned}
& \left(p^{C}-c\right) Q\left(p^{C}\right)-\frac{\tau}{2}\left[\left(p^{C}-c\right) Q\left(p^{C}\right)+\left(p^{C}-p^{B}\right) Q^{B}-\left(p^{B}-c\right) Q\left(p^{C}\right)\right]= \\
& \left(1-\frac{\tau}{2}\right)\left(p^{C}-c\right) Q\left(p^{C}\right)-\frac{\tau}{2}\left[\left(p^{C}-p^{B}\right) Q^{B}-\left(p^{B}-c\right) Q\left(p^{C}\right)\right]
\end{aligned}
$$


We can see that:

- A tax on damages acts like a combination of a tax on profits (first term on expression on RHS above), plus an overcharge-based tax (second term on RHS), plus a subsidy to output (third term on RHS).

- In the "first-best" world in which $\tau=2$, a cartel would set $p^{C}=p^{B}$ - there is no possibility of getting more than but-for profits.

- In a second-best world where $\tau<2$ it would set a price below the monopoly price, as under an overcharge-based regime. If the cartel was faced with a penalty on profits (first term on RHS only would be relevant) then it would set the monopoly price. The second term (tax on overcharge) induces the cartel to reduce price (given the fixed counterfactual output volume) and the third term (subsidy on output) induces the cartel to increase its output: thus, the second and third terms explain why the cartel's optimal price under a damages-based penalty regime would be below the monopoly price. 